\title{
Health care service for leprosy patients in Sitanala Tangerang ( $A$ proposed approach of comprehensive health care for Leprosy patient)
}

Yunia Irawati

Faculty of Medicine, Universitas Indonesia and Jakarta Eye Center, yunia_irawati@yahoo.com

Yeni Dwi Lestari

Faculty of Medicine, Universitas Indonesia

See next page for additional authors

Follow this and additional works at: https://scholarhub.ui.ac.id/ajce

Part of the Social and Behavioral Sciences Commons

\section{Recommended Citation}

Irawati, Yunia; Lestari, Yeni Dwi; Bani, Anna Puspitasari; Menaldi, Sri Linuwih; Wahyuni, Luh Karunia; and Kurniawardhani, Dewinta Retno (2018). Health care service for leprosy patients in Sitanala Tangerang (A proposed approach of comprehensive health care for Leprosy patient). ASEAN Journal of Community Engagement, 2(2).

Available at: https://doi.org/10.7454/ajce.v2i2.142

Creative Commons License

\section{(c) (i) ()}

This work is licensed under a Creative Commons Attribution-Share Alike 4.0 License.

This Research Article is brought to you for free and open access by the Universitas Indonesia at ASEAN Journal of Community Engagement. It has been accepted for inclusion in ASEAN Journal of Community Engagement. 


\title{
Health care service for leprosy patients in Sitanala Tangerang
}

\section{(A proposed approach of comprehensive health care for Leprosy}

\section{patient)}

\author{
Yunia Irawatia*, Yeni Dwi Lestaria, Anna Puspitasari Bania, Sri Linuwih \\ Menaldia, Luh Karunia Wahyunia ${ }^{a}$, Dewinta Retno Kurniawardhani ${ }^{b}$ \\ ${ }^{a}$ Faculty of Medicine, Universitas Indonesia \\ bFaculty of Medicine, Gadjah Mada University, Indonesia
}

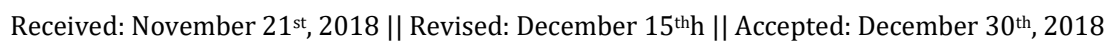

\begin{abstract}
Based on WHO data, Indonesia has the third largest leprosy burden in the world, after India and Brazil. Although leprosy was declared to be eliminated in several provinces, there are still several leprosy settlements spread in Indonesia. One of these settlements is Neglasari village in Tangerang City, West Java, where leprosy patients have been living since 1981. There is a scarcity of information regarding the features of leprosy in Indonesia, especially about the description of the patients' posttreatment condition in terms of both clinical sequelae and health services provided. A collaboration between multiple departments of Ophthalmology, Dermatovenereology, and Medical Rehabilitation from the Cipto Mangunkusumo Hospital/Universitas Indonesia, Jakarta, was established in the form of a health service program to determine the number and features of disabilities of ex-leprosy patients. We provide health services, including physical examinations, extend free medication and eye glasses, and impart knowledge about the chronic complications to patients and local cadres. A nonroutine health service program for leprosy patients was conducted in Neglasari village, which performed four primary activities of promotive, preventive, curative, and rehabilitative. The program included a total of 260 patients, with a mean age of $50.45 \pm 10.15$ years and most of them being males (60.4\%). A duration of $>5$ years of leprosy was found in $47 \%$ of subjects, and $96 \%$ of them have been released from treatment. Disabilities comprised $52.5 \%$ in the eye, $87.7 \%$ in the hand, and $92 \%$ in the foot. In total, $65 \%$ of the patients had an uncorrected visual acuity of normal to mild impairment, whereas $5.8 \%$ were blind. Eye abnormalities included madarosis (43.9\%), entropion (41\%), cataract (26\%), corneal hypoesthesia $(20.6 \%)$, trichiasis $(17.8 \%)$, and lagophthalmos (15.1\%), and examination of the extremities revealed that $16 \%$ of the subjects had an amputated foot. Spectacles were successfully distributed to $100 \%$ of patients who were visually correctable. This proposed model for leprosy health care program involving multidisciplinary expertise is effective for screening numerous disabilities in leprosy patients at one time. This enables caretakers to determine a holistic management that at the end is intended to improve the quality of life of patients.
\end{abstract}

Keywords: leprosy, health care service, disabilities

\section{Introduction}

Leprosy is a chronic infectious disease caused by Mycobacterium leprae that attacks the skin, peripheral nerves, mucosa of the upper respiratory tract, and eyes. It can be

*Correspondence Author: yunia_irawati@yahoo.com 
Yunia Irawati, Yeni Dwi Lestari, Anna Puspitasari Bani, Sri Linuwih Menaldi, Luh Karunia Wahyuni, Dewinta Retno Kurniawardhani | ASEAN Journal of Community Engagement | Volume 2, Number 2, 2018

transmitted via droplets and through direct and frequent contact with M. leprae-infected skin. M. leprae multiplies slowly with an average incubation period of 5 years, although it has been reported that symptoms may develop within 1 year or as long as 20 years in some cases (WHO, 2018). The factors that influence the spread of leprosy are the pathogenicity of M. leprae, modes of transmission, immunological status, individual genetics, and socioeconomic and environmental circumstances (Wisnu, et al. 2016; Fitness, Tosh \& Hill 2002). Due to the presence of human immunity, only a few people could be infected with leprosy bacteria after contact with leprosy patients. Physiological factors such as puberty, menopause, pregnancy, and factors of infection and malnutrition can improve the clinical changes in leprosy. Most of the people (95\%) are immune to leprosy, and only a small proportion (5\%) are infected. Of the 5\% who are infected, about 70\% can heal themselves and 30\% manifest symptoms (Department of Health, 2012).

Leprosy is primarily found in developing countries, especially in tropical and subtropical regions such as Asia, Africa, and Latin America, which is due to the limitation in providing adequate services in the fields of health and education, complicated by low levels of social and economic welfare in the community. Southeast Asia is a region comprising developing countries with the highest number of new leprosy cases in the world, the number being estimated at as many as 154,834 in 2014. Indonesia is one of the developing countries with the highest number of new cases of leprosy in Southeast Asia and the third in the world after India and Brazil (Hogeweg 2010; WHO 2016). Till date, leprosy is a health problem in Indonesia, despite the declaration of leprosy elimination in 2000, and the situation of leprosy is relatively static in Indonesia (Ministry of Health 2016).

The number of leprosy cases reported from countries of all the WHO regions was estimated at 176,176 at the end of 2015 , or 0.18 cases per 10,000 population, with 211,973 new cases or 0.21 cases per 10,000 population (WHO, 2016), whereas at the end of 2016 , there were 173,358 cases with a prevalence rate corresponding to 0.29 cases per 10,000 population, and 216,108 new leprosy cases were reported from six WHO regions (WHO, 2018). In 2016, the Indonesian Ministry of Health announced that there were 16,826 new cases of leprosy (6.5/100,000 inhabitants), with $84.19 \%$ of cases harboring the multibacillary (MB) type. According to gender, $62.47 \%$ of new leprosy patients were males and $37.53 \%$ of them were females. Most of the provinces in Indonesia have achieved elimination, whereas 11 provinces remain endemic, including East Java, North 
Yunia Irawati, Yeni Dwi Lestari, Anna Puspitasari Bani, Sri Linuwih Menaldi, Luh Karunia Wahyuni, Dewinta Retno Kurniawardhani | ASEAN Journal of Community Engagement | Volume 2, Number 2, 2018

Sulawesi, Gorontalo, Central Sulawesi, West Sulawesi, Southeast Sulawesi, South Sulawesi, Maluku, North Maluku, Papua, and West Papua (Ministry of Health, 2017).

Leprosy settlements in Indonesia comprise villages where leprosy patients who are either currently receiving or have completed the series of medication stay and live. One of these settlements is Sitanala located in Neglasari District, Tangerang City. It is named as Sitanala due to its proximity to the Sitanala Hospital, a leprosy-specific hospital established in 1956. This village built around 1980 was intended to temporarily accommodate leprosy patients being treated at Sitanala Hospital from all provinces in Indonesia who did not want to return to their original homes due to the negative stigma they received from their families or people around them, until they can build their own houses. Over time, this settlement became congested and more than half of the population are now ex-leprosy patients. These people are staying and living until now in this settlement (RSK Sitanala, 2018).

According to the WHO leprosy classification, leprosy is classified into two types, paucibacillary (PB) and MB. The PB type has few lesions appearing on the skin (1-5 lesions), with asymmetrical distribution and showing negative result to bacteriological tests, whereas the MB type has more than five lesions, with symmetrical distribution and showing positive result to bacteriological tests (Wisnu, et al 2016). Leprosy patients generally have lesions around the face and tend to suffer from hand and foot disabilities. Initially, the signs and symptoms of people infected with leprosy bacteria involve primarily the skin, nerves, and mucous membranes. The major symptoms of leprosy include skin lesions with decreased sensation (touch, temperature, or pain) and muscle weakness. If left untreated, it causes signs of advanced leprosy such as shortening of toes and fingers caused by reabsorption, paralysis, crippling of extremities, loss of eyebrows, and blindness (Courtright et al. 2002).

Leprosy is also associated with the highest frequency of ocular complications (Rathinam 2010), which can be sight-threatening, causing severe visual impairments that can lead to blindness. Furthermore, blindness can be influenced by several factors, especially steroid treatment in leprosy reactions, the leprosy type, duration of illness, late management of eye disorders, and social barriers due to patient ignorance or health workers that limit access to eye disorders (Hogeweg, 2010). The presence of blindness along with another form of deformity will significantly reduce the quality of life of these leprosy patients and lead to a condition known as "double handicap." 
Yunia Irawati, Yeni Dwi Lestari, Anna Puspitasari Bani, Sri Linuwih Menaldi, Luh Karunia Wahyuni, Dewinta Retno Kurniawardhani | ASEAN Journal of Community Engagement | Volume 2, Number 2, 2018

Leprosy is treatable with multidrug therapy (MDT), which consists of a three-drug regimen, including rifampicin, dapsone, and clofazimine, with a duration of treatment between 6 months for the PB type and 12 months for the MB type. For adults and children aged $>2$ years who are in regular contact with leprosy patients, a single-dose rifampicin regimen is recommended as stated in the guidelines (WHO, 2018). To stop the transmission of leprosy, complete multidrug regimen therapy and BCG vaccination is strongly recommended. The goals of MDT are breaking the chain of transmission, preventing drug resistance, shortening the treatment period, increasing the treatment compliance, preventing the occurrence of deformities, and averting the deterioration of deformities existing prior to treatment (Department of Health 2012).

Most of the leprosy patients have low education and low socioeconomic status that render them more vulnerable and increase the risk of double handicaps. Limited access and cost of treatment to tertiary health services are also obstacles that delay these leprosy patients to admit themselves only when they have experienced vision-threatening complications. This delay carries the consequence of finding more patients with complex disabilities. There is practically no information regarding the condition of patients in this chronic state or after release from treatment, thus necessitating a system that can help address these problems. Furthermore, the negative stigma arising from the environment make people affected with leprosy unwilling to seek medical help. Most of the people surrounding leprosy patients are not aware of the cause of leprosy. Most of them assume that the causes of leprosy are curse, bad blood, heredity, punishment for sins, and eating certain types of food (Tabah et al, 2018; Naaz et al 2017). A study conducted in Indonesia in 2017 by Susanto et al. found that self-care groups can increase the adherence of leprosy patients to completing the medication program. Motivation, guidance, and continuous support for leprosy patients are highly required to provide both positive effect on selfacceptance and constructive effect in accepting people with the disease (Susanto 2017).

It is expected that this health service can be sustainable, can help detect early abnormalities caused due to leprosy, help provide treatment for ex-leprosy patients who already have disabilities, and provide knowledge about leprosy to former sufferers and local cadres for the continuity of health education. The purposes of this program are to determine the number of disabilities experienced by ex-leprosy patients, provide health care services such as conducting examinations and provision of free medication and eye glasses, and share knowledge to patients and local cadres. 
Yunia Irawati, Yeni Dwi Lestari, Anna Puspitasari Bani, Sri Linuwih Menaldi, Luh Karunia Wahyuni, Dewinta Retno Kurniawardhani | ASEAN Journal of Community Engagement | Volume 2, Number 2, 2018

\section{Methods}

Our social health care service program was conducted by a team of doctors from three departments, namely Ophthalmology, Dermatovenereology, and Medical Rehabilitation, from Cipto Mangunkusumo Hospital/Universitas Indonesia, Jakarta, at a leprosy settlement village in Tangerang City. The program was conducted in April 2018 for 2 days, with four primary activities involving promotive, preventive, curative, and rehabilitative program.

This program was led by an ophthalmologist team that invited members from other departments of Dermatolovenereology and Medical Rehabilitation. We collaborated and coordinated to strengthen the concept of this program. We planned for the schedule, prepared the examination flowchart and examination forms, and surveyed the location. We met the director and the board of Sitanala Hospital to present this proposed program and to gather information about leprosy around the hospital. Coordination with the staff from Sitanala Hospital and local community leaders was made to help the team gather the participants. Two weeks before the program, we collected the data of ex-leprosy patients and then informed them about the program. The location selected was Sitanala Hospital Sport Hall, which is near and accessible from their houses. Cadres were contacted from the Head of Neglasari primary health care and were invited to the program.

A total of 265 subjects came in for the examinations for 2 days, of whom 260 subjects completed all the examinations. During the program, each patient underwent three examinations involving the eye, skin, and extremities. Patients consented through verbal and written forms before participation, after receiving information and explanation from the team regarding the purpose of the program, risk and side effect, advantages, procedure, and confidentiality of the patient's identity.

The health service started with history-taking (anamnesis) of general information, history of health and disease, completing a questionnaire, and continuing with the series of examinations. The ophthalmology examination was aimed at detecting the abnormalities of the eyes. A total of 5 ophthalmologists, 11 general practitioners, and 2 refractionists collaborated in the examination. The examination involved determination of the uncorrected and best corrected visual acuity using a Snellen chart, corneal sensitivity using Cochet Bonet aesthesiometry, tear production test using Schirmer paper, and examination of the anterior segment using slit lamp and the posterior segment when 
Yunia Irawati, Yeni Dwi Lestari, Anna Puspitasari Bani, Sri Linuwih Menaldi, Luh Karunia Wahyuni, Dewinta Retno Kurniawardhani | ASEAN Journal of Community Engagement | Volume 2, Number 2, 2018

needed (if visual acuity was not synchronized with the anterior segment examination) using direct funduscopy with 90D lenses. The dermatology examination was conducted by six dermatologists and six general practitioners, including inspection of skin abnormalities and deformities of the hand and foot and sensory examinations. Six specialists in medical rehabilitation with the help of 29 general practitioners conducted examination of the extremities. Deformities and motor functions of the extremities of leprosy patients were evaluated and recorded, which consisted of assessment of upper and lower extremities. The flowchart of the examination is shown in Figure 1, and some pictures taken during the program are shown in Figure 2.

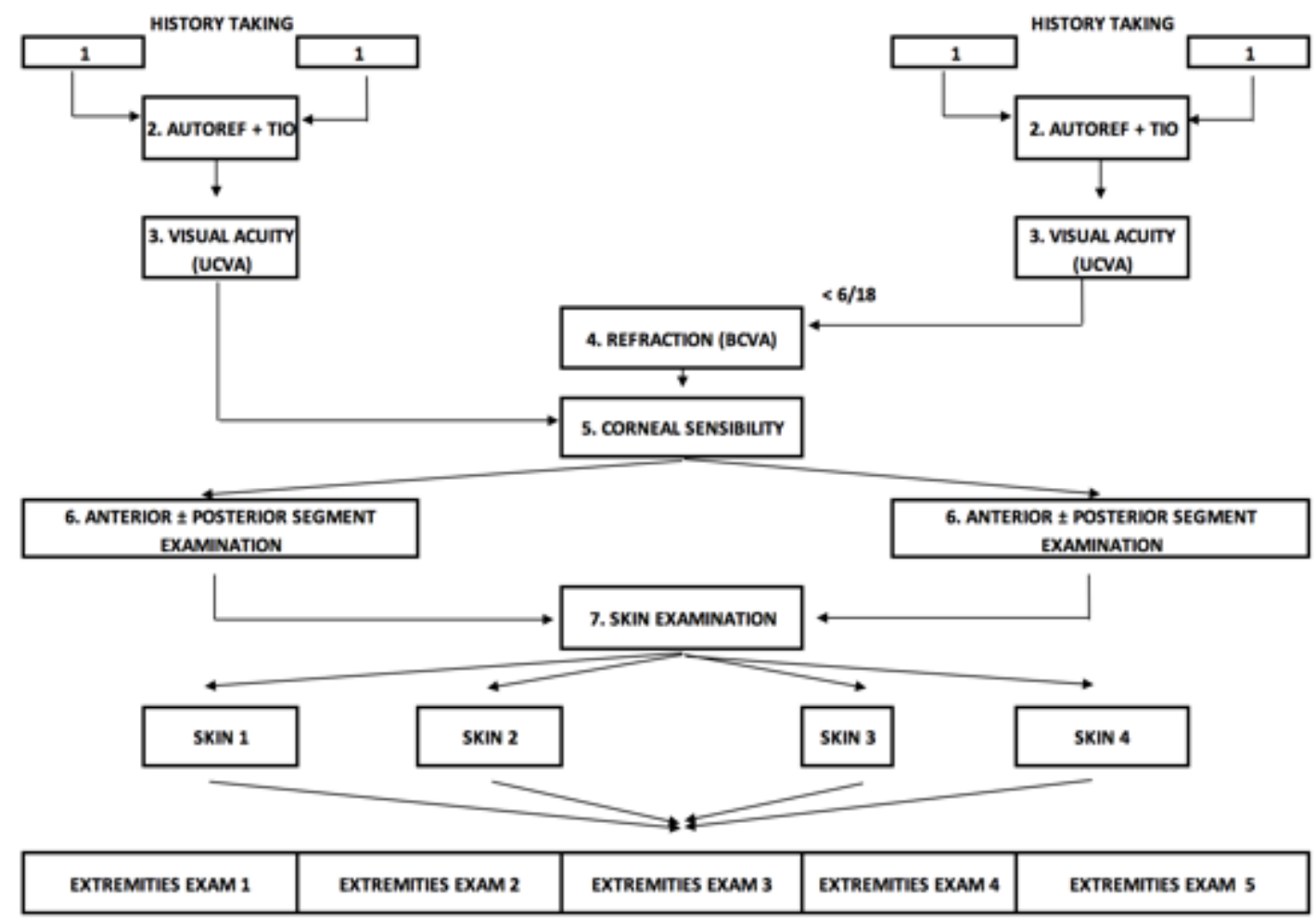

Fig. 1 Flowchart of examinations

The ophthalmology examination aimed to detect abnormalities of the eyes. Five ophthalmologists, 11 general practitioners, and 2 refractionists collaborated in the examination. The examination involved visual acuity examination with uncorrected and best corrected visual acuity using Snellen chart, corneal sensitivity using Cochet Bonet aesthesiometry, tear production test using Schirmer paper, and anterior segment examination using slit lamp and posterior segment when needed (if visual acuity was not synchronized with the anterior segment examination) using direct funduscopy with 90D 
Yunia Irawati, Yeni Dwi Lestari, Anna Puspitasari Bani, Sri Linuwih Menaldi, Luh Karunia Wahyuni, Dewinta Retno Kurniawardhani | ASEAN Journal of Community Engagement | Volume 2, Number 2, 2018

lenses. The dermatology examination was performed by 6 dermatologists and 6 general practitioners, including inspection of abnormality on the skin and deformities of the hand and foot and sensory examinations. Six specialists in medical rehabilitation with the help of 29 general practitioners performed the extremities examination. Deformities and motoric functions of the leprosy patient's extremities were evaluated and recorded, which consisted of assessment of upper and lower extremities. Several pictures during the program in Fig. 2.

a

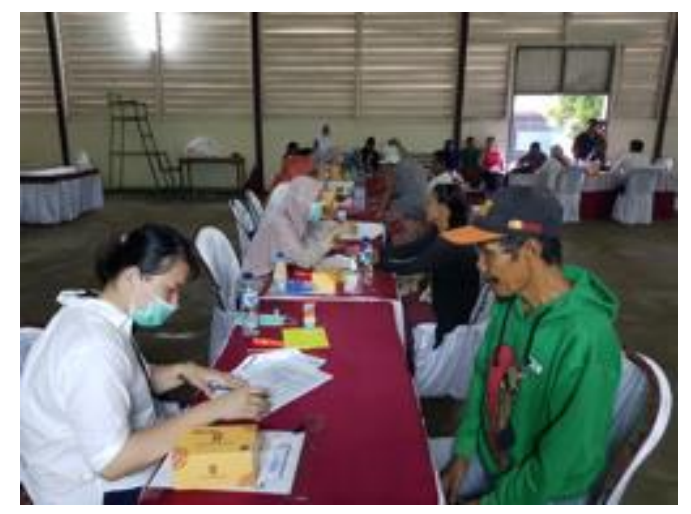

C

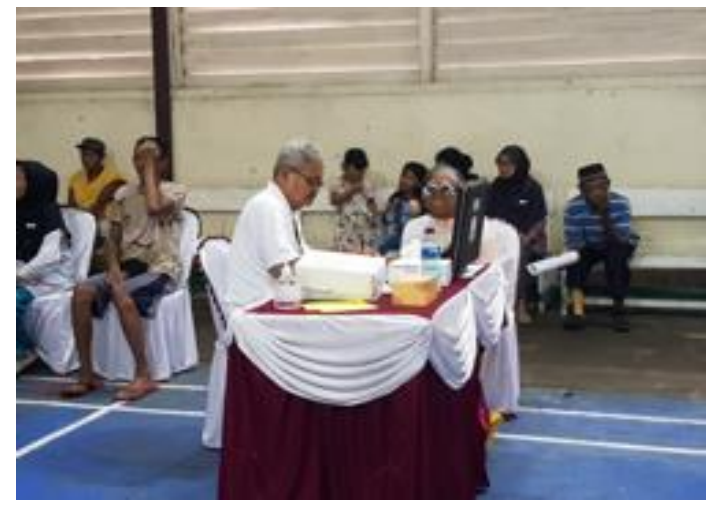

e

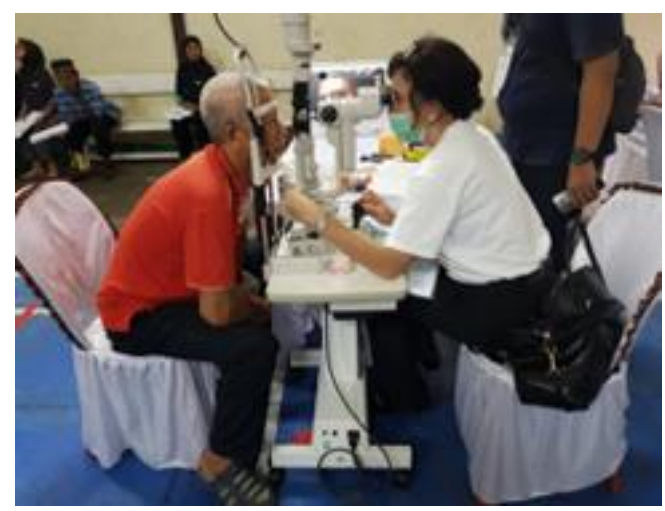

$\mathrm{d}$

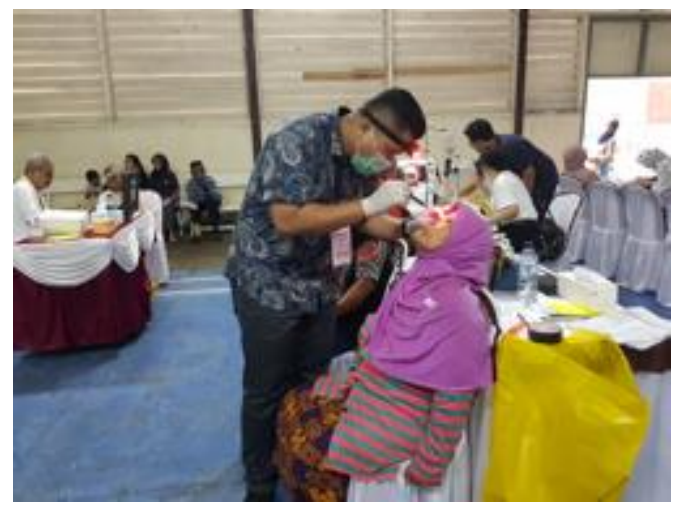

b
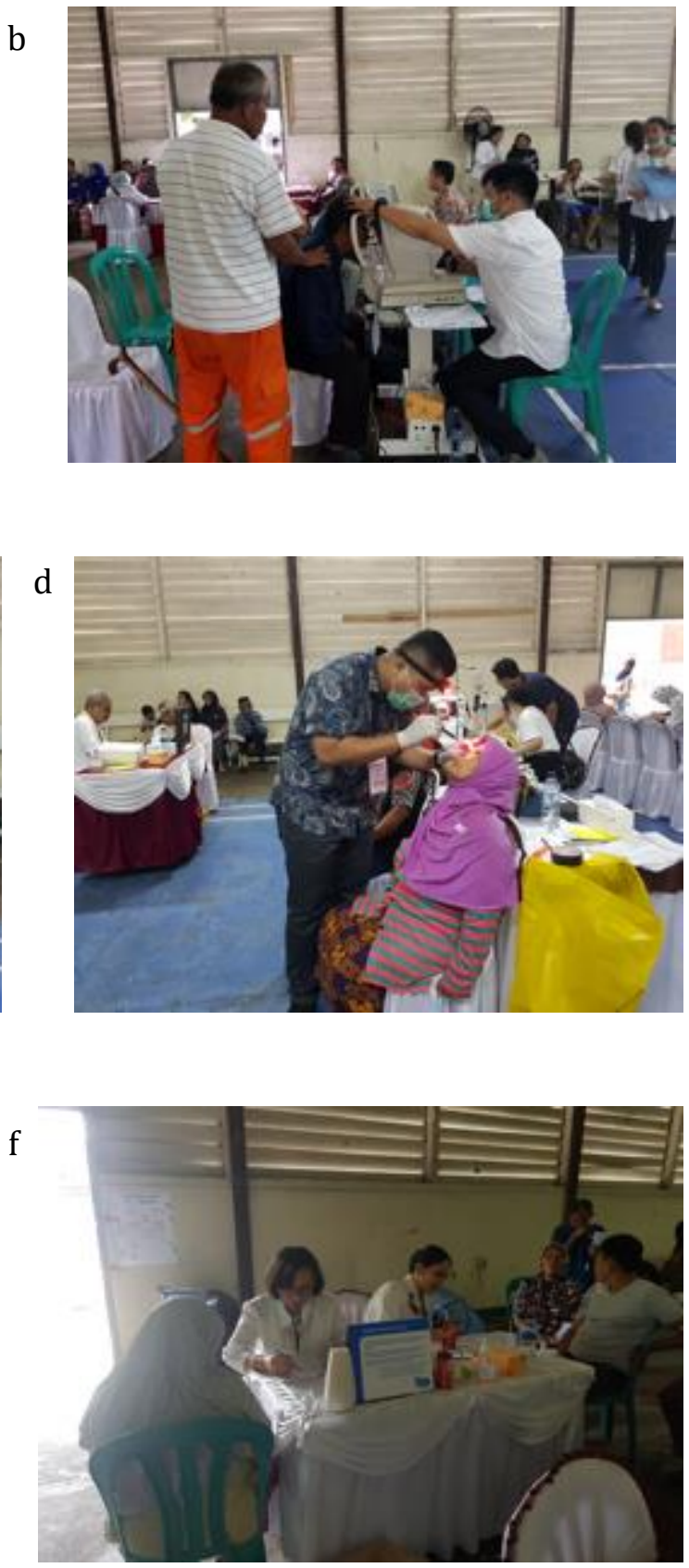

Kurniawardhani | ASEAN Journal of Community Engagement | Volume 2, Number 2, 2018

g

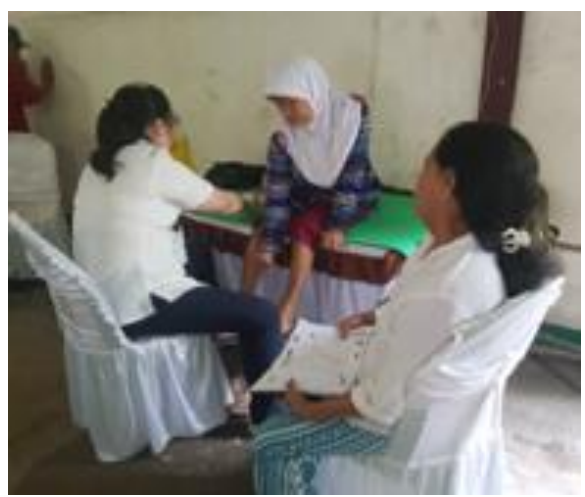

$\mathrm{h}$

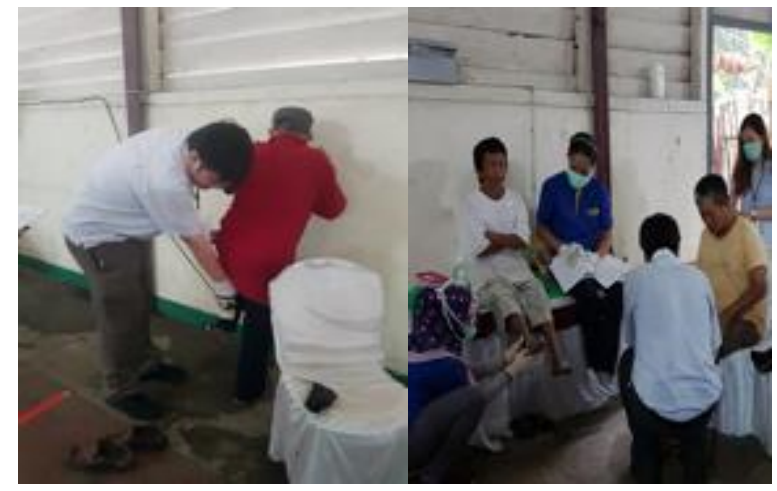

Fig. 2 (a) history taking; (b) autorefraction and TIO examination; (c) BCVA examination; (d) corneal sensibility examination; (e) anterior segment examination; (f) skin examination; (g) hand examination; (h) foot examination

In addition to the abovementioned examinations, counseling regarding prevention, detection, and self-care for the patients and their families was given. The counseling was intended to help patients and their families toward the early recognition of signs and symptoms of leprosy, how to prevent disease transmission if one of their family members is affected with leprosy, and how to take care of the abnormalities or deformities caused due to leprosy (Figure 3A). During the presentation, the doctor provided several details about leprosy, such as (1) Leprosy is caused by a germ and not a curse or hereditary, (2) People who get infected with leprosy can be cured with MDT in some period of time, (3) Leprosy cannot be spread via casual touch, for example, shaking hands, playing, or working together, (4) Leprosy generally starts with a patch finding on the skin with loss of touch and pain sensation; the patch can occur anywhere on the entire body, and (5) Complete MDT regimen can prevent permanent deformities and can stop transmission to other people.

We invited seven cadres from Neglasari District, known as WASOR (Vice Supervisor) Cadre, to attend an in-depth discussion guided by specialists on the second day of the program. This discussion was aimed at imparting leprosy knowledge and sharing experience when facing leprosy patients (Figure 3B). The specialists provided information about wound-care management for leprosy patients, extremity exercises with ball-squeeze movement to prevent further contracture in patients who have had deformities, and steps to motivate and bring people suspected with leprosy and leprosy patients to see a doctor regularly. 
a

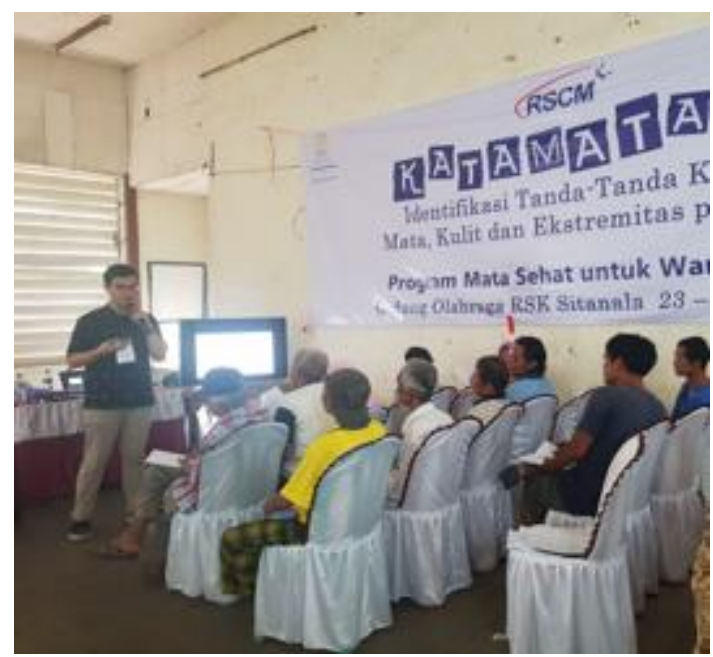

$\mathrm{b}$

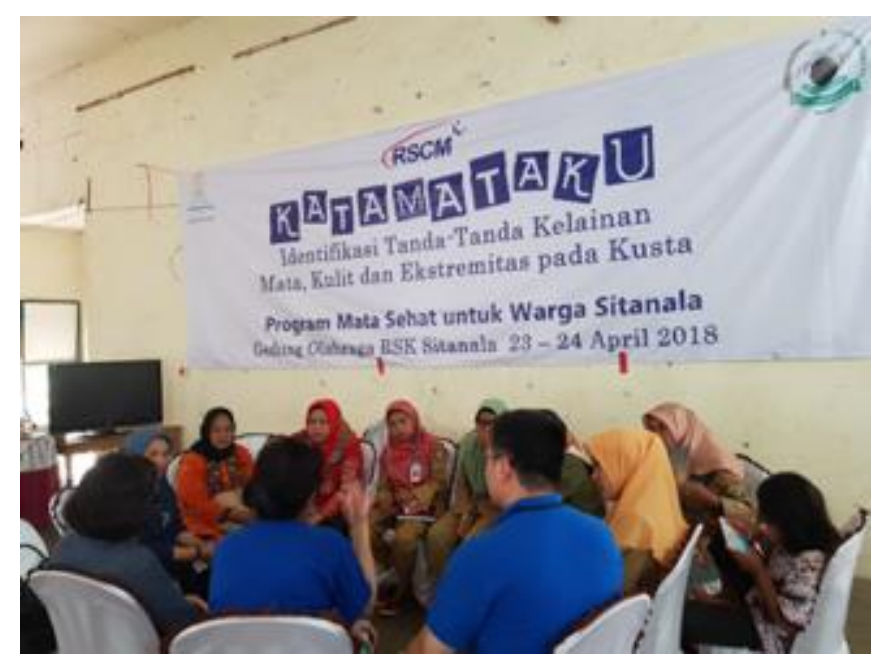

Fig. 3(a) Leprosy education to ex-leprosy patients. (b) Sharing and discussion with local cadres led by specialists from multiple departments of Medical Rehabilitation, Dermatoveneorology and Ophthalmology

\section{Result and Discussion $\leftarrow$ Cambria, Bold, 12 pt}

A total of 265 subjects attended the program, of whom 260 subjects meeting the inclusion criteria were enrolled in the study. The mean age of these enrolled patients was $50.45 \pm 10.15$ years, with a male:female ratio of $1.5: 1$. Regarding their leprosy status, $96 \%$ of them were non-active leprosy cases, 96\% were released from treatment, and the duration of leprosy was $>5$ years, as shown in Table 1 .

Table1. Demographic data

\begin{tabular}{lcc}
\hline Variable & \multicolumn{2}{c}{ Total subjects(n=260) } \\
\cline { 2 - 3 } & $\mathrm{n}$ & $(\%)$ \\
\hline Mean age (Mean \pm SD) & & $50.45 \pm 10.15$ \\
N/A (22 patients forgot) & &
\end{tabular}

Gender

Male 
Yunia Irawati, Yeni Dwi Lestari, Anna Puspitasari Bani, Sri Linuwih Menaldi, Luh Karunia Wahyuni, Dewinta Retno Kurniawardhani | ASEAN Journal of Community Engagement | Volume 2, Number 2, 2018

\begin{tabular}{clc}
\hline Variable & \multicolumn{2}{l}{ Total subjects $(\mathrm{n}=260)$} \\
\cline { 2 - 3 } & $\mathrm{n}$ & $(\%)$ \\
\hline Female & 103 & $(39.6)$
\end{tabular}

Duration of leprosy

$<2$ year

2-5 year

92

$>5$ year

Unknown

18

Type of leprosy

PB

1

MB

2

Release/Non-active leprosy

249

Unknown

8

Treatment status

Drop out

2

Release from treatment

Unknown

9

\subsection{Eye Abnormalities}

For the visual acuity examination, we performed two examinations consisting of uncorrected visual acuity (UCVA) without the use of glasses or lenses and best corrected visual acuity (BCVA) using lenses. Then, we made four classifications based on the WHO Vision Impairment Classification as follows: mild or no visual impairment (visual acuity $\geq 6 / 18$ ), moderate visual impairment (visual acuity $<6 / 18$ to $\geq 6 / 60$ ), severe visual impairment (visual acuity $<6 / 60$ to $\geq 3 / 60$ ), and blindness (visual acuity $<3 / 60$ to no light perception).

By categorizing patients based on UCVA, they were grouped as follows: $65 \%$ had mild or no visual impairment, $26.5 \%$ had moderate visual impairment, $2.7 \%$ had severe visual impairment, and 5.8\% were blind (Table 2). Among patients with distant correctable 
Yunia Irawati, Yeni Dwi Lestari, Anna Puspitasari Bani, Sri Linuwih Menaldi, Luh Karunia Wahyuni, Dewinta Retno Kurniawardhani | ASEAN Journal of Community Engagement | Volume 2, Number 2, 2018

refractive error $(n=58)$, all $(100 \%)$ received spectacles, and among patients in need of additive lenses $(n=106)$, all $(100 \%)$ received additive lenses, with 52 in the form of bifocal glasses. After the prescription of spectacles, there was a change in the abovementioned proportions as follows: $78.4 \%$ had mild or no visual impairment, $15.3 \%$ had moderate visual impairment, 1.9\% had severe visual impairment, and $4.2 \%$ were blind, indicating an overall increase of $13.4 \%$ of patients in the mild or no visual impairment group and a decrease in the moderate, severe, and blindness groups.

Table 2. WHO Classification of Visual Impairment $(n=260)$

\begin{tabular}{|c|c|c|c|c|c|}
\hline \multirow[t]{2}{*}{ Classification } & \multicolumn{2}{|c|}{ UCVA } & \multicolumn{3}{|c|}{ BCVA } \\
\hline & $\mathrm{n}$ & $(\%)$ & $\mathrm{n}$ & & $(\%)$ \\
\hline Mild or & 169 & $(65)$ & & 204 & \\
\hline impairment & & & & & $(78.4)$ \\
\hline Moderate & 69 & $(26.5)$ & & 40 & \\
\hline impairment & & & & & (15.3) \\
\hline \multirow[t]{2}{*}{ Severe visual impairment } & 7 & $(2.6)$ & & 5 & \\
\hline & & & & & (1.9) \\
\hline \multirow[t]{2}{*}{ Blindness } & 15 & $(5.8)$ & & 11 & \\
\hline & & & & & $(4.2)$ \\
\hline
\end{tabular}

After visual acuity examination, an anterior segment examination of the eye was performed to observe the presence of any abnormality that most often results from leprosy. A total of 257 patients completed the anterior segment examination, with $43.9 \%$ of them experiencing madarosis. Madarosis is a condition where the patient's eyebrows or eyelashes undergo thinning or are lost due to the leprosy process. Other adnexal abnormalities such as trichiasis, ectropion, and entropion in one or both eyes of the patient were commonly found. Lagophthalmos is a condition where the eyelids cannot close normally; it is often an advanced complication of the eye caused due to leprosy and was found in 39 subjects. Other conditions found in patients caused due to leprosy were obstruction in the tear ducts, dacryocystitis, epiphora (excessive tear conditions due to 
Yunia Irawati, Yeni Dwi Lestari, Anna Puspitasari Bani, Sri Linuwih Menaldi, Luh Karunia Wahyuni, Dewinta Retno Kurniawardhani | ASEAN Journal of Community Engagement | Volume 2, Number 2, 2018

dry eye conditions), corneal hypoesthesia, cataract, episcleritis, scleritis, iris pearls, iritis, and punctate keratitis, as shown in Table 3.

Table 3. Anterior Segment Abnormality ( $\mathrm{n}=257)$

\begin{tabular}{lllll}
\hline & Yes & $(\%)$ & No & $(\%)$ \\
\hline Madarosis & 113 & 43.9 & 144 & 56.0 \\
Trichiasis & 46 & 17.8 & 211 & 82.1 \\
Ectropion & 18 & 7.0 & 239 & 92.9 \\
Entropion & 41 & 15.9 & 216 & 84.0 \\
Lagophthalmos & 39 & 15.1 & 218 & 84.8 \\
Epiphora & 13 & 5.0 & 244 & 94.9 \\
Dacryocystitis & 1 & 0.3 & 256 & 99.6 \\
Cataract & 67 & 26.0 & 190 & 73.9 \\
Corneal hypoesthesia & 53 & 20.6 & 204 & 79.3 \\
Episcleritis & 0 & 0 & 0 & 0 \\
Scleritis & 0 & 0 & 0 & 0 \\
Iris pearls & 15 & 0.38 & 256 & 99.6 \\
Iritis & 3 & 1.16 & 254 & 98.8 \\
Keratitis punctate & & 5.83 & 242 & 94.1 \\
N/A & 0 & & \\
\hline
\end{tabular}

The three most common ocular abnormalities found in the patients were madarosis, followed by cataract and corneal hypoesthesia. It must be noted with caution that all the ocular abnormalities might not be related per se to leprosy. The findings depicted in Table 3 were detected in this specific population in the settlement. However, when related to leprosy and the profound adnexal involvement and its complications, entropion (15.9\%), lagophthalmos (15.1\%), and trichiasis (17.8\%) should raise our concern, in terms of both number and clinical significance. All these abnormalities, along with corneal hypoesthesia, increase the risk of sight-threatening conditions. 
Yunia Irawati, Yeni Dwi Lestari, Anna Puspitasari Bani, Sri Linuwih Menaldi, Luh Karunia Wahyuni, Dewinta Retno Kurniawardhani | ASEAN Journal of Community Engagement | Volume 2, Number 2, 2018

According to the literature, eye disorders related to leprosy can occur in all types of leprosy, but they are more common in MB types. Based on the pathogenesis of leprosy that divides this disease into a tuberculoid and lepromatous type, ocular manifestations also differ. In the tuberculoid type, ocular manifestations are unilateral, with rare intraocular manifestations. Extraocular manifestations commonly involve the eyelid, especially if there is a lesion on the branch of the 7th cranial nerve that innervates the orbicularis oculi muscle. Extraocular lesions could include superciliary and ciliary madarosis, entropion, ectropion, lagophthalmos, dry eye, and epiphora. The lepromatous type runs slower, with abnormalities being more symmetrical and include common intraocular manifestations such as conjunctival hyperemia, episcleritis, scleritis, corneal hypoesthesia/anesthesia, septic keratitis, interstitial keratitis, exposure keratitis, corneal ulceration, chronic iritis (iris pearls, iris atrophy, iris and pinpoint pupils, nonreactive pupils and irregular pupils, and posterior synechiae), iridocyclitis, and cataracts (Grzybowsi et al. 2015; Ebenezer et al. 2016; Lewallen et al. 2012).

Patients with eye complications must be given treatment and intervention immediately to reduce the risk of further worsening or progression into blindness. During the program, the team of doctors also gave artificial eye drops to help reduce the effects of dry eyes and prescribed antibiotic drops if there were signs of eye infection (Figure 4). In this study, cataract, trichiasis, entropion, and lagophthalmos should and can be improved with an operative approach, and leg prosthesis can improve functioning of extremities. It has been documented that 42 lower extremities could be aided by prosthetics. Several patients $(n=26)$ have already been using prosthetics that are now unfortunately in a poor condition.

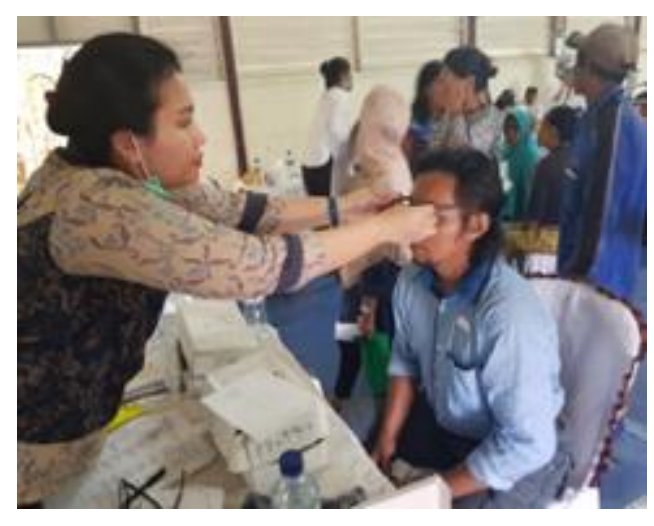

Fig. 4 Distribution of eyeglasses and medication 


\subsection{Severity of Leprosy}

Of the total 260 subjects, 253 had complete data regarding the severity of leprosy; the data of 7 subjects were not available. The proportions of disabilities were as follows: $92 \%$ (foot), 87.7\% (hand), and 52.5\% (eye) (Table 4). When combining the upper and lower extremities, the overall disabilities were anesthesia of a part of the hand or leg, muscle paralysis, ulcus, clawing, stiffness, drop hand, drop wrist, drop foot, and absorption. In this program, a moisturizer cream was given to moisten the skin and to prevent further ulcus caused by dryness of the skin and bacteria due to their low hygiene.

Table 4. Disability of Leprosy $(n=253)$

\begin{tabular}{lcccc}
\hline & \multicolumn{5}{c}{ Disability } \\
\cline { 2 - 5 } & Yes & $(\%)$ & No & $(\%)$ \\
Eye & 133 & $(52.5)$ & 120 & $(47.4)$ \\
Hand & 222 & $(87.7)$ & 31 & $(12.2)$ \\
Foot & 233 & $(92)$ & 20 & \\
\hline
\end{tabular}

As shown in Table 4, the patients primarily had multiple disabilities, where one disability might lead to another, or worsen each other, increasing the overall morbidity. In addition, although three departments have participated, considering the disabilities involved, it is suggested that in the future collaboration with the departments of Psychiatry and Orthopaedics could contribute to an even larger benefit.

\section{Conclusion}

A proposed model for the leprosy health care program with multi-department collaboration is highly effective in detecting multiple disabilities of leprosy patients at one time and in increasing the awareness of this neglected transmissible disease to patients and community. The coordination and collaboration with hospital staff and local community leaders were highly efficient in the collection of many ex-leprosy patients in the village for this proposed program. 
Yunia Irawati, Yeni Dwi Lestari, Anna Puspitasari Bani, Sri Linuwih Menaldi, Luh Karunia Wahyuni, Dewinta Retno Kurniawardhani | ASEAN Journal of Community Engagement | Volume 2, Number 2, 2018

Considering the high and multiple number of disabilities, this condition is likely to be caused due to the delay in admittance and diagnosis and thus the consequent treatment. In addition, social stigma and self-stigma can be large contributing factors for seeking regular treatment. Altogether, leprosy has a deep impact on the quality of life and function of the patients in carrying out their daily activities.

\section{Acknowledgements}

This work is supported by the Community Engagement Grant of 2018, DRPM (Directorate of Research and Community Engagement) Universitas Indonesia, Sitanala Hospital, Topcon Industries and Cendo Company for their medical equipment and medicamentous support and Directorate P2 of Direct Transmitted Disease, Director General P2P Health Ministry of Indonesia (Seksi Kusta dan Frambusia/ Direktorat Penyakit Tropis Menular Langsung/ Direktorat P2 Penyakit Menular Langsung/Ditjen P2P Kementrian Kesehatan RI).

\section{References}

Courtright, P, Daniel, E, Sundarrao, Ravanes, J \& Mengistu, F. (2002). Eye disease in multibacillary leprosy patients at the time of their leprosy diagnosis: findings from the Longitudinal Study of Ocular Leprosy (LOSOL) in India, Philippines and Ethiopia. Lepr Rev, vol. 73, pp. 225-238.

Ebenezer D. (2016). Ocular Leprosy. In: Kumar B, Kar HK, editors. IAL Textbook of Leprosy 2nd ed. New Delhi: Jaypee Brothers Medical Publishers; p. 370-93.

Fitness, J, Tosh, K \& Hill, A. (2002) Genetic susceptibility to leprosy. Genes Immun, vol. 3, pp. 441-453.

Grzybowsi A, Malgorzata N, Virmond M. (2015). Ocular leprosy. Clin Dermatol, vol. 33, pp. 79-89.

Hogeweg, M. (2010). Leprosy and the eye teaching set. pp. 1-41. International Centre for Eye Health, London.

Kemenkes. (2012). Tata Laksana Program Kusta di Indonesia. Kementerian Kesehatan RI, Jakarta. 
Yunia Irawati, Yeni Dwi Lestari, Anna Puspitasari Bani, Sri Linuwih Menaldi, Luh Karunia Wahyuni, Dewinta Retno Kurniawardhani | ASEAN Journal of Community Engagement | Volume 2, Number 2, 2018

Kemenkes. (2016). Pedoman Nasional Program Pengendalian Penyakit Kusta. Kementrian Kesehatan RI Direktorat Jendral Pengendalian Penyakit dan Penyehatan Lingkungan Jakarta.

Kemenkes. (2017). Profil Kesehatan Indonesia Tahun 2016, in D Budijanto, Yudianto, B Hardhana \& TA Soenardi, (eds), pp. 166-169. Kementrian Kesehatan RI, Jakarta.

Kemenkes. (2018). Hapuskan Stigma dan Diskriminasi terhadap Kusta. Kementrian Kesehatan RI, Jakarta.

Lewallen S, Courtright P. Ocular involvement in leprosy. (2012). In: Nunzi E, Massone C, editors. Leprosy a practical guide: Springer-Verlag;p. 247-54.

Naaz F, Mohanty PS, Bansal AK, Kumar D, Gupta UD. (2017). Challenges beyond elimination in leprosy. Int J Mycobacteriol, vol. 6, pp.222-228.

Rathinam, SR. (2010). Leprosy uveitis in the developing world. Int Ophthalmol Clin, vol. 50, pp. 99-111.

RS Kusta Dr. Sitanala. (2018) Hospital by Laws Rumah Sakit Kusta Dr. Sitanala Tangerang 2018.p. 1.

Susanto T, Dewi EI, Rahmawati I. (2017). The experiences of people affected by leprosy who participated in self-care groups in the community: A qualitative study in Indonesia. Lepr Rev, vol. 88, pp543-553.

Tabah EN, Nsagha DS, Bissek AZ, Njamnshi TN, Njih IN, Pluschke G, Njamnshi AK. (2018). Community knowledge, perceptions and attitudes regarding leprosy in rural Cameroon: The case of Ekondotitiand Mbonge health districts in the South-west Region. PLoS Negl Trop Dis, vol. 12, p. e0006233.

WHO. (2016). Global Leprosy Strategy 2016-2020, World Health Organization, from: http://apps.searo.who.int/PDS_DOCS/B5233.pdf?ua=1. [January 2017].

WHO. (2016). Global Leprosy Strategy 2016-2020, World Health Organization, from: http://www.searo.who.int/srilanka/areas/leprosy/global_leprosy_strategy_2016 _2020.pdf

WHO. (2018). WHO to publish first official guidelines on leprosy diagnosis, treatment and prevention, from: http://www.who.int/neglected_diseases/news/WHO-topublish-first-guidelines-on-leprosy-diagnosis/en/. [June 2018].

WHO. (2018). Leprosy. Available from: http://www.who.int/news-room/factsheets/detail/leprosy. [February 2018]. 
Yunia Irawati, Yeni Dwi Lestari, Anna Puspitasari Bani, Sri Linuwih Menaldi, Luh Karunia Wahyuni, Dewinta Retno Kurniawardhani | ASEAN Journal of Community Engagement | Volume 2, Number 2, 2018

Wisnu, IM, Sjamsoe-Daili, ES \& Menaldi, SL. (2016). Kusta, in SL Menaldi, K Bramono \& W Indriatmi, (eds), Ilmu Penyakit Kulit dan Kelamin, 7th edn, pp. 87-102. Badan Penerbit Fakultas Kedokteran Universitas Indonesia, Jakarta.

WHO. (2018). WHO to publish first official guidelines on leprosy diagnosis, treatment and prevention, from: http://www.who.int/neglected_diseases/news/WHO-topublish-first-guidelines-on-leprosy-diagnosis/en/. [June 2018].

WHO. (2018). Leprosy. Available from: http://www.who.int/news-room/factsheets/detail/leprosy. [February 2018].

Wisnu, IM, Sjamsoe-Daili, ES \& Menaldi, SL. (2016). Kusta, in SL Menaldi, K Bramono \& W Indriatmi, (eds), Ilmu Penyakit Kulit dan Kelamin, 7th edn, pp. 87-102. Badan Penerbit Fakultas Kedokteran Universitas Indonesia, Jakarta. 